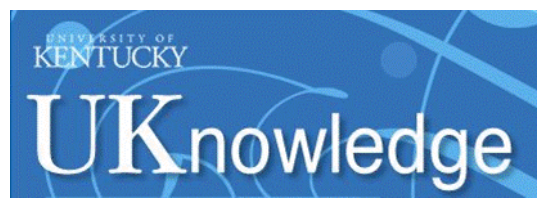

University of Kentucky

UKnowledge

\title{
Rethinking Social Change: The Promises of Web 2.0 for the Marginalized
}

David Nemer

University of Kentucky, david.nemer@uky.edu

Follow this and additional works at: https://uknowledge.uky.edu/slis_facpub

Part of the Library and Information Science Commons

Right click to open a feedback form in a new tab to let us know how this document benefits you.

\section{Repository Citation}

Nemer, David, "Rethinking Social Change: The Promises of Web 2.0 for the Marginalized" (2016).

Information Science Faculty Publications. 84.

https://uknowledge.uky.edu/slis_facpub/84

This Article is brought to you for free and open access by the Information Science at UKnowledge. It has been accepted for inclusion in Information Science Faculty Publications by an authorized administrator of UKnowledge. For more information, please contact UKnowledge@lsv.uky.edu. 
Rethinking Social Change: The Promises of Web 2.0 for the Marginalized

Digital Object Identifier (DOI)

https://doi.org/10.5210/fm.v21i6.6786

Notes/Citation Information

Published in First Monday, v. 21, no. 6.

Authors retain copyright to their work published in First Monday.

"Rethinking social change: The promises of Web 2.0 for the marginalized" by David Nemer is licensed under a Creative Commons Attribution 4.0 International License.

This article is available at UKnowledge: https://uknowledge.uky.edu/slis_facpub/84 


\title{
Rethinking social change: The promises of Web 2.0 for the marginalized by David Nemer
}

\begin{abstract}
This paper focuses on the uses of Web 2.0 platforms by residents of favelas, urban slums in Brazil, in order to expand our understanding of what Web 2.0 can and cannot do in terms of social change. To explore this problem space, I draw on a 10-month ethnography in the favelas of Vitória, Brazil to study slum residents' Web 2.0 practices and engagements. I show how Web 2.0 afforded favela residents the ability to protest and cross social boundaries, but when that happened they faced something much stronger: social exclusion, police brutality against the blacks and poor, and limited civic engagement.
\end{abstract}

\section{Contents}

Introduction

Methodology and context

Empowered until crossing social boundaries: The Orkutization of shoppings

Showing up late to the party: The social movement of the marginalized

Final thoughts

\section{Introduction}

Web 2.0 technologies have initiated a new age of the Web with promises to empower its users, to promote creativity, and to democratize information production (see O'Reilly, 2007). Such technocratic rhetoric has lead the general public to the notion that Web 2.0 platforms, such as social media, indicate some grand authoritative social change, in which they promote democratic and inclusive discussions and activities (Nemer, 2015a). As evaluated by Brake (2014), many authors of contemporary books and popular media assume that Web 2.0 platforms are beneficial-or, at the very least, play a benign role in society. For example, studies and news articles ranging from Twitter revolutions in Egypt and Iran (see Howard and Hussain, 2011; Mansour, 2012), to bridging the digital divide in the Global South (see Kaplan and Haenlein, 2010; Morgan, 2011), have emphasized the active and fundamental part taken by Web 2.0, as if it had its own agency to promote social progress.

However, strong critiques of Web 2.0 have also emerged from scholars who were concerned with providing a more realistic and grounded analysis of the uses of the Internet (see boyd, 2014; Fuchs, 2012; Hargittai, 2002; Ito, et al., 2010). A strand of research, especially focused on the Internet in the Global South, has challenged such positivist view of the Web 2.0 (see Kamel, 2014; McLennan, 2015; Rangaswamy and Nair, 2012; Wyche, et al., 2013). Although these studies recognize the Web 2.0 as a tool that may afford citizenship and empowerment, they question such emancipatory promises since those who face social and digital marginalization have yet to experience them. This study joins, strengthens, and extends such critical approaches of Web 2.0 by focusing on the use of social media by residents of favelas, urban slums in Brazil. It expands our understanding of what Web 2.0 can and cannot do in terms of social change. In order to explore this problem space, I draw on a 10-month ethnography, including user observations, and 56 in-depth semi-structured interviews of favela residents in Vitória, Brazil to study slum residents' Web 2.0 practices and engagements. The fieldwork focused on four Community Technology Centers (CTCs): two LAN houses [1] and two telecenters.

I analyze two cases that illustrate Web 2.0 affordances and to what extent they promote social change for slum residents: (1) "Rolézinhos," which translates as "little strolls," where young people from lower classes arranged meetings on Facebook to leave their low-income communities to hang out at malls, places traditionally associated with the white and rich; and (2) "The Protests of June 2013," when students and Brazil's upper class organized protests on social media, and because of the social and digital inequalities in Vitória, favela residents had a limited experience of the protests. In these two cases I show how Web 2.0 afforded favela residents to protest and cross social boundaries, but when that happened 
they faced something much stronger: social exclusion, police brutality against the blacks and poor, and limited political engagement.

\section{Methodology and context}

Ethnography is a natural fit in order to better understand cultural understandings of the value technology provides. Due to the nature and context of this ethnography within marginalized favelas of Brazil — this study appropriates the tone and ethical responsibility found in a specific group within ethnography, which is called critical ethnography (see Carspecken, 1996; Denzin, 2001; Gordon, et al., 2001; Madison, 2012). Critical ethnography is grounded in critical theories that assume society is structured by class and status, and this structure maintains the oppression of marginalized groups. It has the ethical responsibility to address processes of unfairness or injustice, such as the ones lived by favela residents, and to uncover the hidden texts and experiences of the oppressed.

The methodology affords the research with a sense and commitment based on principles of human freedom, wellbeing and, a compassion for the suffering of living beings (Madison, 2012). It provides the researcher with a tool to resist domestication and it repositions the researcher from "what is" to "what could be" (Denzin, 2001). It places marginalized people at the center of the research and posits that people themselves define what they value, which will likely result in a plurality of views. As called for in ethnography, this paper avoids a top-down approach. Goals and hypothesis are not defined a priori but instead applied in an open-ended process of public deliberation that puts the views of the people whose lives are affected at the heart of the research.

The field site for this paper was the neighboring favelas of Gurigica, São Benedito, Bairro da Penha, and Itararé located in the city of Vitória, capital of the state Espírito Santo, Brazil. Favelas are considered "wrong" places for studying technology because they are outside the main economic, technological and political centers. Although they are in the periphery, studying "wrong" places allows us to learn a lot about place and their persisting importance in today's "knowledge economy" (Takhteyev, 2012). Just like other urban slums, these favelas fit a typical unauthorized and informal urban settlement. They are areas occupied by squatters and are often lacking public services or urbanization. Due to the state's absence in favelas, non-state armed groups, who control drug dealing and use violence to enforce contracts and maintain power, emerged in 1980 (Ferraz and Ottoni, 2014). These cartels maintain the order in the favela by enforcing their own laws. The drug lords are respected by the residents because they create an environment in which critical segments of the local population feel safe despite continuing high levels of violence (Perlman, 2010).

The most famous favelas, like Rocinha and Cidade de Deus (City of God), in Brazil are in the city of Rio de Janeiro. In order to prove the city can be a peaceful venue for the World Cup in 2014 and the Olympic Games in 2016, the police began expelling drug traffickers out of Rio, and the ones who escaped attempted to hide inside favelas in nearby cities, such as Vitória (do Val, 2012). Their presence in Gurigica turned the slum into a war zone. The drug lords from Rio de Janeiro teamed up with the rival cartel from Bairro da Penha and and sought control territories in Gurigica and São Benedito neighborhoods. Thus, performing ethnography in such areas was challenging and risky. For instance, I found myself in the middle of three shootings between rival gangs; however, due to the goodwill and assistance of the community leader, who helped me gain access to the favelas, the LAN house owners, and to the Inclusion Agents [2], who were locals, allowed me to learn my way around and gain trust from key informants.

As is the case with most favelas, most of Gurigica, São Benedito, Bairro da Penha and Itararé's population relies on LAN houses and telecenters to access computers and the Internet. I conducted the fieldwork from June to July 2012, and then April to October 2013. This fieldwork focused on two LAN houses: Life Games, in Itararé, and Guetto, in Gurigica; and two telecenters: one in Itararé and another in São Benedito. I visited two CTCs per day five times a week, and then changed CTCs the following week. This weekly CTCs swap happened until the end of the fieldwork and allowed me to optimize the time I spent at each CTC. The data collected for this paper were drawn from user observations, field notes, Facebook interactions [ $\underline{3}$ ], and 14 in-depth and semi-structured interviews in each CTC (with an average of 35-60 minutes per interview). The selected users visited the CTCs at least twice a week, 30 were female and 26 were male, and they fit into two age groups: 15-24 and 24-45. I also interviewed and interacted on Facebook with the LAN house owners and telecenters' Inclusion Agents. The initial focus was to gain a greater understanding of the field's context and to understand the locals' experience in the CTCs.

During the time of this study, I lived in my hometown, Vitória. My residence was proximate to the research site, which was just 20 minutes away by foot (about one mile from Itararé). It was located in an upper class neighborhood, in spite of the proximity to the favela, I was unfamiliar with the area of study. However, this created a useful distance that, when combined with the empathy of my approach, allowed me to see beyond what would be considered mundane or uninteresting at the site. I was aware of the differences of power and status that my background would bring: male, upper class and also a researcher. However, in order to alleviate the barriers that such differences may have caused, I approached the informants as "conversational partners": listening with an open heart and kindly receiving what they had to express (Rubin and Rubin, 2012). The motivation was not to judge the informants but rather to understand them. Such attitude is 
perceived as being fully engaged with the art of listening sympathetically, in which the researcher is actively thinking about what is being expressed. This dynamic avoided the rigid back and forth replay of question-answer-question that is conventionally conducted in formal interviews (Madison, 2012).

The first 21 interviews were recorded using a Tascam DR-05 audio-recorder, with the remaining 35 interviews conducted using Google Glass [4]. The informants were aware of the recording devices, and provided informed consent. All names mentioned in this paper have been changed to protect anonymity. I transcribed the interviews and later translated them to English. I changed recording devices in response to demands from members of the drug cartel who were uncomfortable with the Tascam DR-40's resemblance to a Taser, and did not want the device in their territory, asking me to "put the audio-recorder away." The Google Glass, however, did not seem to be a problem to the drug cartel, since they were unaware of what it was.

The interviews, field notes, and observational data were coded using MaxQDA software, which aided me in visualizing and organizing the data. I conducted a thematic analysis and identified emerging patterns of social media use by the participants. Based on the analysis, I chose the quotes and vignettes that were most representative of each theme. The patterns of social media use were used to answer the questions asked in this paper in the light of the objective of promoting social change. The ethnographic approach ultimately sought to situate technology appropriation and use by the participants in their daily lives within rich socio-technical dynamics that played out in the favelas' CTCs.

\section{Empowered until crossing social boundaries: The Orkutization of shoppings}

The favela residents often witnessed frequent shootouts between traffickers and against the police. The shootouts were related to territory wars and crime fighting, respectively. Walking around and visiting friends and family in the favelas was highly dangerous, not only because of the shootouts but also because territory boundaries shifted quite often as they were divided among the drug lords in informal treaties and agreements. It was hard for residents to know which drug lord their area belonged to and where it would be safe for them to stay. This situation often left families divided and unable to communicate, a consequence of such invisible walls set by the drug cartels. Maria, 45 years old, a frequent user of the telecenter in Itararé summed up her experience:

"My daughter lives with her family in Bairro da Penha. I haven't been able to see her for more than one month ... I live in Itararé and I don't have enough credits on my cell phone to call her every day ... and attempting to go up the hill to see her is too risky. I never know when all hell will break loose ... It makes me sad because I can't see my two-year-old granddaughter growing up ... The telecenter is not ideal because it is limited, but it has helped me keeping in touch with them. She goes to the LAN house next to her house and we get on Facebook and chat, exchange the Lord's words, she sends me photos of my granddaughter and we even play games sometimes ... It is not the same as us being together, but at least I can rest assured that they are safe."

The computers at the CTCs were heavily used for Facebooking and entertainment purposes. The informants from all age groups spent most of their time on Facebook chatting, watching videos, listening to music from YouTube, playing Facebook and other flash-based games, and gastando [ㅁ]. Such uses of computers were important because they drew people into digital worlds and improved their technological skills, along with language skills, information-seeking skills, and targeted browsing skills. They also afforded people the ability to exercise their relationships by providing a safe channel for them to keep in touch with their relatives and friends.

Based on my observations in the CTCs, Facebook has turned into the users' main social media; all of the informants had a Facebook account and were active users. The popularity of Facebook was surprising because Orkut was Brazil's number one social networking site (SNS) until 2012 (Nemer and Freeman, 2015; Nemer, 2013), but only four of the informants, out of 56, still used it. Part of the reason for this transition was explained as a response to wider social trends:

"Nowadays you have to have a Face [Facebook] to connect to people on and offline. No one asks for your phone number anymore, they all want to know if you have a Face" (Jose).

As the lower classes in Brazil gained more access to basic services and technology, such as the Internet, they originally desired to be part Orkut. Their presence in the social network was not well received by first adopters, people from upper classes, who had created several communities on Orkut geared towards making fun of the way "poor people" used Orkut. In such communities, these first adopters mocked the poors' online and off-line habits, deeming their posts "low 
educated." There were a few Web sites, such as PerolasDoOrkut.com.br (Gems of Orkut), dedicated to finding and documenting such "gems," and disseminating them with mocking words and out of context comments.

"I'm not on Orkut ... I wanted to be on as many sites [social media] as possible because I want to communicate with everyone. But I had to quit Orkut. I did not feel comfortable there ... there were several communities mocking poor people from the favelas. When you first look at those photos, they seem funny, but then you realize that you could be on those photos. I left Orkut before they [mocking Web sites] found my stuff and now I'm just on Face." (Alice, 16 years old)

The lower classes' access to and behavior on Orkut was labeled "Orkutização" (Orkutization). The term was later extended to label things that became too popular, that were accessed by the poor, and that were deteriorated by their habits, and was used to refer to online and off-line life (Reis, 2014). As mentioned by Alice, the Orkutization was also one of the reasons why some of the informants courageously moved to Facebook - which was only in English at the time and thus more exclusive to richer classes, who had English-language skills. As observed, the people from the favelas migrated to Facebook or chose it as their first SNS, but the prejudice persisted on posts that talked about the Orkutization of Facebook, as demonstrated by Ricardo, 21 years old:

"There are all kinds of open groups you can join on Facebook, like Utilidade Pública [Public Interest]. I have joined the group but I just read stuff there ... I don't dare to post anything. They make fun of your looks, your Portuguese, and when you have a question, they will call you favelado [ 6$]$ and tell you to study.”

The mocking Web sites also adapted to this change of SNSs; they changed their names in order to broaden their "hunt for the gems of the poor." For example, at the time of the fieldwork, PeroloasDoOrkut.com.br had changed its name and URL to just Perolas.com. Such behavior suggested that the upper classes did not want the "untamed" poor in the same place as them; based on their posts, they were not interested in understanding the favela residents' background and motivations to behave differently. The online prejudice contributed to distance the already segregated poor classes in Vitória's society, as mentioned by Leticia, 27 years old:

"Everyone at my job get along really well ... we play and joke all the time. I also wanted to have that here [on Facebook] ... but some people there live at Praia do Canto and Santa Lucia [rich neighborhoods] and I'm afraid to be judged or even embarrass my friends on their own Face."

Despite the present prejudice observed on Facebook, favela residents still ventured on the SNS and organized their own groups. Facebook groups became popular especially with favela teenagers, as they perceived it as a way to freely communicate with friends and other teenagers from the same social class without fear judgment. Some teenagers went beyond the communicative aspect of groups and shared self-made digital content in order to become what were called famosinhos. Famosinhos were the most popular teenagers from the favelas. They dictated fashion trends among teens within the favelas, and actively cultivated their reputation by producing videos and content to promote ostentation. They were influenced by Funk Ostentation [7] in their media productions, and often showed their Nike or Puma shoes, expensive brand t-shirts, such as Lacoste and Polo, or even their thick gold necklaces. Such access to material good put them in a higher power position when compared to other teenagers, some of whom became fans. João, 17 years old, summarized how he became a famosinho:

"They say that being famous on Facebook is like being rich in the board game Monopoly: the money is useless ... But it doesn't matter because I have this [clothes]; I want to be like those MCs from Funk Ostentation. My fans look up to me, give me lots of respect ... and I earned it! I spent several hours at the telecenter and attended the workshops to learn new tools and to be creative ... Now I can make videos and talk for my peers about what we want and what we need ... being a famosinho also gives the opportunity to fight for what we want."

Famosinhos from the favelas organized meetings on Facebook so they could hang out with friends and meet their fans. These meetings were called rolézinhos (meaning "little strolls") and later became a phenomenon throughout Brazil. Larissa, a famosinha from São Benedito, had more than 500 likes on her Facebook page. She mentioned that she was invited as a special guest to local birthday parties and the local "baile funk" - dance clubs in favelas that played funk music. She showed me the photos of the rolézinho, which was promoted by her fans at the public square in Itararé where more than 200 people showed up:

"I learned that a boy, a big fan, shaved his head to look like me. When he met me, he started crying. Everyone was touched by that moment" (Larissa). 
At first, the rolézinhos were taking place in public squares in the peripheries of the city, but they turned out to be popular enough that the famous teenagers dared to organize the strolls in local shopping malls (e.g., Shopping Vitória), or just "shoppings" as they were called. In Brazil, shoppings provided more than an act of entertainment or a place to hangout and shop for the latest goods; instead, they functioned as a situated activity where the upper class demonstrated their purchasing power and social location (Bienenstein, 2009) []. Based on my observations, favela residents perceived shoppings as a place to feel more included in society. These places allowed them the opportunity to show that they also had money (purchasing power) and access to expensive, trending goods, and not just cheap and old garments. Thus, their motivation was mostly centered on consumerism as a function of power and prestige.

The shoppings were located centrally in the cities and not in the favelas. Since this mean crossing social if not political boundaries, it was not well received, and the famosinhos and their fans were soon labeled as troublemakers, thieves, and rioters because they were in big groups and were targeted as favelados. According to Recuero (2014) rolézinhos became a statement of inclusion of marginalized people in what was always understood to be a wealthy person's place (the malls):

"hundreds of Facebook pages invited the young and poor to the malls all around the country. A number of rolézinhos took place, and several malls started closing their doors on the scheduled rolézinho dates. More people started attending and organizing the events as a way to protest against social division and prejudice in the country."

Thais, a fan of João, was disappointed by how João's rolézinhos were recriminated by the police and the people at the mall. She saw the meetings organized through Facebook as a powerful way to show society who they were and what they wanted:

"We didn't want to cause any harm, we just wanted to walk around with our famosinhos, hang out with our friends, take photos at the mall so we could upload them to Face [Facebook] ... I finally ate at McDonald's, which was like a dream come true ... I can't go there by myself ... I'd be tortured by those judging eyes. It's sad that the police are treating us like that ... We don't have cool stuff here in the favela like they have at the mall ... I will organize more rolézinhos on Face so we can go as a group and be persistent with what we want ... which is just to have fun."

João's rolézinho hit the popular news outlets in Vitória, such as A Gazeta (see Miranda, 2013); however the articles presented the members of the gathering as rioters and looters, which influenced Vitória society's opinions about rolézinhos, increasing the misjudgments and prejudice of the favela teens. The newspapers did not report the police repression, but the members of rolézinho reported on police activity, and this scared and deterred some favela residents from crossing boundaries and participating in the shoppings, as explained by Jaciara, 18 years old:

"I knew this was going to happen, every time I go to Shopping Vitória, the people that work there always look at me with a weird eye ... I don't like it, it seems that they don't want me there, or that I will steal something. Now I have one more reason [police repression] to not go there anymore. I rather do online shopping here at the LAN [house]."

As explained by Jaciara, favela residents did not feel welcome at the malls and used online shopping as a way to circumvent their marginalization. However, it was difficult for the post office to deliver packages in the favelas due to violence and unofficial territory demarcations. The CTCs eventually evolved as mail distribution hubs to help residents overcome this limitation.

In summary, this case highlights how favela residents were able to creatively and actively appropriate SNS in a way that made sense and was of value to them, but did not help crossing boundaries through rolézinhos. Rolézinhos, both speaks to and moves beyond what boyd (2014) called "networked publics": an important public space enabled by social media where teens can gather, informally socialize with each other, and engage in political action. According to the author, these teens look for a place of their own to make sense of the world beyond their bedrooms. However, in the case of favela teens, such public spaces are not wholly constituted by online activity in the way that Facebook communities are considered the quintessential "networked public" [i.e., a public afforded and made possible by networked technology]. In this case, although the networked technology plays an important coordinating roll, it is not the primary site of the activity of the stroll itself, which is the shoppings. Instead, the publics in rolézinhos follow Warner (2005) and the argument that counterpublics enable marginalized individuals to create communities that resist hegemonic publics. Rolézinho members wanted access to publics to see and be seen, to socialize, and to feel as if they have the freedom and power to explore a world beyond that shaped by those in higher classes and positions of power.

Rolézinho was a phenomenon that helped me understand that favela residents were not only marginalized due to their social conditions, but they were also marginalized by place — that is place, both online and physical, functioned as point 
of control over the favela residents. The prejudice suffered by the favela residents in the shoppings was similar to what they experienced on Orkut, as explained before: the upper classes, according to my observations, did not seem to want to be in a situation where they had the same power and affordances as the poor and did not want either online or physical boundaries to be crossed.

João's use of social media empowered him to become a famosinho and a tech savvy user of the CTCs, leading him to reach his goals, which was to consume goods as a way to reach greater social inclusion. João's case is evidence of Neri's (2012) observation that people from poor classes do have more access to goods; however, this way to pursue social inclusion is problematic since it is molded and dictated by economic and consumerist forces, which in the end only provide superfluous inclusion, prestige, and bounded or constrained power (Pochmann, 2013). Unfortunately, the rolézinhos phenomenon follows the mimicry of Homi Bhabha (1994), in which the favela residents copy the rich and adopt their value systems rather than representing their own voices: the disciplined upper classes see poor teenagers wearing brands of the hegemonic market for which they serve and wear, but do not legitimize these teenagers, whose bodies seem to need to be tamed. The upper classes do not recognize the "Other" (poor) and feel a deep and uncomfortable disorder because of such access through the rolézinhos.

\section{Showing up late to the party: The social movement of the marginalized}

On 30 October 2007 Brazil received news that it was selected to host the 2014 FIFA World Cup. The announcement was celebrated by Brazilians as if the country had won its sixth title; people were wearing the traditional green and yellow and had hopes that the government would finally solve the country's fundamental problems with education, health care, infrastructure and crime. Six years later, as Brazil was getting ready to host FIFA Confederations Cup, an official test event for the World Cup, the excitement that enthralled the Brazilian people turned into deep frustration.

In June 2013, an avalanche of protests led more than one million people to take to the streets in over a hundred cities in Brazil. The wave of protests began in early June in the city of São Paulo and spread throughout the country. The protests were motivated by an eight percent increase $(\mathrm{R} \$ 0.20)$ in fare for public transportation (Saad-Filho, 2013). The protests grew to include a much larger set of issues faced by Brazilian society. For instance, the protesters were dissatisfied with the government due to either a perceived or real increase in corruption and impunity (Trigo, 2013). They were also frustrated by the cost of hosting the upcoming World Cup and Olympic games in light of this economic disparity and the lack of decent public services, such as health care, education and security. Citizens wanted assurance that the economic gains that would come from these world events would be used to improve social services.

In Vitória, the first protest took place on 17 June 2013. University students and members of the Brazilian middle class organized it; they used Facebook to form two popular groups: "Utilidade Publica - ES" (referred as UP) (Public Utility - ES) and "Não é por 20 centavos" (referred as N20) (It's not just 20 cents). The initial protest attracted 20,000 people, and the protestors started marching at the Federal University of Espírito Santo (UFES). They marched 11 kilometers, passing through the most important avenues in the city until reaching the official residence of the Espírito Santo's governor, Renato Casagrande (Nossa, et al., 2013). Some protesters carried white flowers and displayed signs of their demands. Interestingly, the protesters had written hashtags on their cardboard signs as a way to link their demands to the conversations on Facebook.

I participated in the protest march to observe the events. I was not able to identify anyone from Gurigica, Itararé, Bairro da Penha, or São Benedito. The protesters were mostly white, and wore clothes that resembled typical upper class citizens. Ironically, they protested for a better, more inclusive society, but then also marginalize the favela residents in things like the shoppings. The following day I went back to the favelas and questioned some of the informants about the protests. Most of them knew little about them, as mentioned by Thais:

"I heard about the protests in Rio and São Paulo on TV, but heard nothing about the one that happened here ... Even if I had, why would I go there? To get beat up by the cops? We already get enough of that here in the community."

I analyzed the list of members in the Facebook's groups [9] that were responsible for organizing the protests and again could not recognize anyone from Gurigica, Bairro da Penha, São Benedito, or Itararé. I posted a message on both groups asking if anyone was from those communities, but did not get a single positive response - I had 36 (on UP) and 48 (on N20) people responding "no" to my posts. Since the group members were mostly students and belonged to the upper classes, the information about the protests never reached Facebook users from marginalized classes. The social divide that took place in Vitória, defined by geographical place and income, was also congruently mapped online as the rich and poor social networks did not overlap.

Due to the large numbers of participants on 17 June, the protest organizers gained interest and attention from mainstream media, and they announced a new protest for 20 June 2013. Since the information about the new protest was available 
through less exclusive and mass channels, like mainstream media, the favela residents became interested and organized their own group on Facebook to come up with a list of demands. To encourage people to join the protesters, Roni used the hashtag "\#VemPraRua" (come out to the streets):

“We can't be afraid of getting beat up ... That's already happening. If we don't do anything then things won't change and my people from the favela will still have no access to education and health care ... I don't want this life ... We already have 107 people in the Facebook group and they all said they are going to the next protest."

The protests of 20 June made history by gathering more than 100,000 protesters in the streets of Vitória. This formed the largest public demonstration ever registered in the state of Espírito Santo (Nossa and Borges, 2013). I also joined these protests with 21 favela residents. They demanded better living conditions in the favelas, more respect as citizens, and they called for an end to the drug war. Roni considered the participation in the protest an important beginning for the residents:

"It is just the start ... we still have a lot to fight for. I wonder if our voices will ever be heard by the politicians ... Facebook turned out to be a good way to reach out for people spread all over the communities ... The group gave the privacy we needed to discuss sensitive and critical issues, such as the drug cartel activities, without getting people in trouble."

Even though the people facing digital inequalities in marginalized areas joined only the second protest, Facebook was able to provide a platform for the favela residents to organize and manifest their demands. However, because they came in late, the demands that were associated with the protests and passed on to government officials were defined by members of upper classes, who were the main organizers of both protests, which was observed by Pedro, 18:

"We get here [protests] and everything is already set up. It doesn't matter how loud we scream; no one will hear us. They [protest organizers] don't care about the drug war in the favelas, or the chaotic situation we live in. They just want to demand what is convenient to them. I don't feel that I'm fully contributing to this protest, I'm just another person here ... It's an illusion. I don't feel like coming back [to another protest]."

In summary, as highlighted in Pedro's testimonial, this case illustrates how social and digital inequalities can affect the way information diffuses within different social classes, affecting the political and civic engagement of the poor.

Some scholars have perceived social media as a place where people from different social worlds and networks have better chances to connect and share content (e.g., Aaker and Smith, 2010; Kaplan and Haenlein, 2010). However, that was not the case of Vitória, where people that belonged to different social classes did not easily connect or share content online. The protests of June 2013 were a good example of such social segregation. The organizers of the first protests belonged to an upper class that did not overlap with lower classes, online and off-line, and thus the marginalized joined in late to the streets and their voices and requests were not as privileged as the ones shouted by the rich. The protests followed Earl and Kimport's (2011) expectation that "social networking sites like Facebook will encourage new uses and dynamics of online protest. With the ability of social networking sites to connect and maintain social relationships as well as telegraph action immediately, these sites might [...] represent collective participation, alerting members of a network when their friend participated in an action" [10], however the events contradict the authors' suggestion that SNS could bring different social worlds together around specific actions, linking people virtually rather than physically.

The findings here presented extends and strengthens existing critical approaches to Web 2.0 (see Earl and Kimport, 2011; Ems, et al., 2012; Tufekci and Wilson, 2012), where SNSs are recognized as an important space for civic and political engagements, but they also amplify pre-existing social tensions [11]. In the case of the protests of June 2013, although Facebook afforded their organization, the findings suggest that it is also important to look at who is organizing and participating in these social movements in order to have a better understanding of where the demands are coming from and who these demands benefit. In Vitória, when the favela residents joined the protests, they joined a group that already had demands stipulated by member from upper classes, who were the first adopters of the protests. As a result, the demands of the disenfranchised were not as amplified as the demands of the upper class. Also, besides the lack of social ties between people from different social classes, the social conditions in which the poor lived also influenced their civic engagement, as mentioned by Roberta, 20 years old:

"Listen, I don't have Internet with me all the time to know what is going on ... I don't have access to that kind of information, and even if I had, how can I go to these protests? I have to work all day long, put bread on the table and take care of my children ... I can't pay anyone to do that for me, besides tomorrow I have to be at work, if I miss one single day, I'm back on the streets ... If I go, how will I return home? By taxi? [ironic laugh] I don't have money for that, also these protests end 
late and things get really dangerous here in Bairro da Penha at night. Even if some changes happen, we all know here [in reference to the people from the favelas] that these changes won't be for us."

As much as the Internet is considered an open and democratic space, these findings also suggest that the ability of a person to engage in protests and civic actions, highly depends on their off-line social location, in which not only they need access to information (in this case the Internet) but also the necessary conditions that would allow them to participate in such activities. It's thus not just access to information, but as Roberta points out, it's access to information at all time and not at discrete times - such as when they are able to make it to the telecenters and the LAN houses.

\section{Final thoughts}

Web 2.0 technologies helped usher in a new age of interaction on the Internet. It proposed a new paradigm where digital content was generated not only by site owners but also by site users. Facebook, Twitter, YouTube, Wikipedia, and WordPress are a few of the online platforms which aim at fulfilling the Web 2.0's philosophy — to democratize the Web and provide users with spaces where anyone can produce content and voice their opinions for others to read, watch, or hear. It is true that Web 2.0 developments have facilitated some democratic events, such as Occupy Wall Street (Conover, et al., 2013; DeLuca, et al., 2012) and Black Lives Matter (Freelon, et al., 2016) movements, and that this affords online participation, however, not everyone is so privileged to benefit from these online platforms. Those for whom the Internet is inaccessible, or not easily accessible, like favela residents become increasingly excluded from mainstream life.

The consequences of digital inequality have been of concern for the past decade. Technology enthusiasts have turned their attention to Web 2.0 as the architecture of increased democracy and social inclusion. As argued by van Dijck and Nieborg (2009), a recurring theme in both academic and popular discourse is that "all [Web 2.0] users are equally creative and are created equal" [12]. However, this is the viewpoint from a privileged society - even though users are now capable of participating actively on the Web, scholars have identified several digital production gaps where online content creators tend to be members of privileged minorities (see Brake, 2014; Schradie, 2011).

The inequalities of accessing information communication technologies (ICTs) and content production are far from being solved since they are rooted in much deeper, complex social, political, and economic factors. However, slowly and unevenly, computers and the Internet are becoming more accessible in marginalized places, such as favelas, and as I described, this has allowed these residents to take advantage of platforms like YouTube and Facebook. However, when we go revisit one of the ideological pillars of the Web 2.0, which is democratization, and contrast it with the cases here presented, we begin to question the ability and capacity of the Web 2.0 architecture to provide the framework for social change and democracy. This is not to say that this critique is novel in the Web 2.0 literature - as I described in the Introduction; however, this study reinforces and expands such critiques by bringing nuances of Web 2.0 uses in favelas, in which is still underrepresented in the literature.

One issue highlighted by Rangaswamy and Nair (2012), is that the literature and popular press have perceived the marginalized as mere consumers of online services, claiming that they are not ready to benefit from the Internet because they did not receive proper training; however, the marginalized peoples' growing experience with technology invites us to revisit such claims and to see these people as agents, active producers and innovators. Like the cases in the favelas, Facebook and YouTube provide a channel for favela residents to exercise their identity, creativity, and political and civic action. But now that they have a presence online (even if that presence is minimal) and share their experiences on the Internet, the intriguing question is whether or not society is ready for them and willing to democratically share the same places (off-line and online).

The findings presented in this study suggest that upper class in Vitória - and I dare to say in the rest of Brazil as well, is not ready and not willing to democratically share the same place of ideas, like on Orkutizided Facebook and shoppings. Favela residents were not welcome beyond their poor communities, and Web 2.0 did not open the door to social integration. These findings do suggest that ICTs have been appropriated in specific ways by the favela residents that help them overcome their limitations, fulfill certain needs and exercise their human agency. However, favela residents have aspirations that extend beyond ICTs, as in the case of the rolézinhos: although the teenagers from favelas felt empowered to cross social boundaries and go for a "little stroll" at the shopping malls, they suffered the same prejudice and discrimination as they always have from the upper class, who did not want such large groups of teenagers invading "their" place. Although Facebook provides a platform for the residents of Bairro da Penha, Gurigica, São Benedito, and Itararé to organize and manifest their demands in the street protest, the social inequalities that take place in Vitória affected the way information flowed, and this affects the ability of the poor to engage politically and civically. The organizers of the first protests belonged to an upper class that did not overlap with lower classes, online or off-line. Since the marginalized arrived late to the streets, their voices and requests were not as privileged. 
As these two cases illustrate, Web 2.0 affords the marginalized to empower and organize to protest and cross social boundaries, but when this happens, they face something much stronger - a social exclusion marked by police brutality against blacks and poor, and limited civic engagement. Web 2.0, or any technology, will not fix these problems because it did not cause them. These problems are rooted in deeper issues that go beyond the domain of technology. Hence, the idea that technology will promote some grand authoritative social change by itself must be criticized further, so it can inform technology designers and politicians in order to promote inclusive policies and ICTs.

\begin{abstract}
About the author
David Nemer is Assistant Professor in the School of Information Science at the University of Kentucky. He is the author of the book Favela Digital: The other side of technology (Editora GSA, 2013).

E-mail: david [dot] nemer [at] uky [dot] edu
\end{abstract}

\title{
Acknowledgments
}

I would like to thank Sean Burns for his feedback and comments that greatly improved this paper.

\section{Notes}

1. LAN Houses are privately owned establishments where, like cybercafés, people can pay to use a computer with a local area network and Internet access. As opposed to LAN Houses, telecenters are facilities supported by the state and NGOs and are places where the general public can access computers for free. LAN Houses and telecenters, along with other technology access establishments, are considered community technology centers (CTCs) (Nemer and Reed, 2013).

2. Inclusion Agents are the people responsible for taking care telecenters. They promote computer workshops and classes and they help the users.

3. I created a new account and used it for this study to keep in touch with the informants.

4. This research went through Indiana University IRB, study number: 1304011173. The Google Glass was used exclusively to audio record interviews and was not used to record people's interactions in public spaces. Before audiorecording the interviews, I talked about the device with the subjects, explained what it was, let them use it, and explained how the data were going to be stored and used. The subjects preferred that I used the Google Glass, instead of the voice recorder, because they could see when they were being recorded - with the voice recorder, as some of them mentioned, they would forget that it was there on the table recording the conversation. For more information on the use of the Google Glass please refer to Nemer (2015b).

5. Gastar is a verb which in English means "to spend" or "to waste." It is used by teenagers in Brazil to describe the activity of hanging out, chitchatting, making comments, and mocking someone. Gastando is the gerund form of the verb gastar.

6. Favelado is a derogatory term to refer to favela residents. It implies that a favela resident is uneducated and uncivilized.

7. Funk in Brazil is very different from what the genre means in other places. Funk is a type of music derived from Miami bass and African style music that became popular in the favelas as a way to show their culture and protest. Funk is often criticized due to violent, sexually explicit content and for degrading women.

8. Shoppings follow Harrison and Dourish's (1996) definition of a place, in which a place is a space which is invested with understandings of behavioral appropriateness, social meaning, conventions, and cultural expectations.

9. $U P$ and $N 20$ had approximately 120,000 users combined.

10. Earl and Kimport, 2011, p. 204.

11. According to Toyama's (2015) "Law of Amplification": Technology's primary effect is to amplify human forces, so in education, technologies amplify whatever pedagogical capacity is already there.

12. van Dijck and Nieborg, 2009, p. 860. 


\section{References}

J. Aaker and A. Smith, 2010. The dragonfly effect: Quick, effective, and powerful ways to use social media to drive social change. San Francisco: Jossey-Bass.

H. Bhabha, 1994.The location of culture. New York: Routledge.

G. Bienenstein, 2009. "Shopping Center: O Fenômeno e sua Essência Capitalista," GEOgraphia, volume 3, number 6, at http://www.uff.br/geographia/ojs/index.php/geographia/article/view/66, accessed 31 May 2016.

d. boyd, 2014. It's complicated: The social lives of networked teens. New Haven, Conn.: Yale University Press.

D. Brake, 2014. "Are we all online content creators now? Web 2.0 and digital divides," Journal of Computer-Mediated Communication, volume 19, number 3, pp. 591-609.

doi: http://dx.doi.org/10.1111/jcc4.12042, accessed 31 May 2016.

P. Carspecken, 1996. Critical ethnography in educational research: A theoretical and practical guide. New York:

Routledge.

M. Conover, E. Ferrara, F. Menczer and A. Flammini, 2013. "The digital evolution of Occupy Wall Street," PLoS ONE, volume 8 , number 5 , e64679.

doi: http://dx.doi.org/10.1371/journal.pone.0064679, accessed 31 May 2016.

K. DeLuca, S.Lawson and Y. Sun, 2012. "Occupy Wall Street on the public screens of social media: The many framings of the birth of a protest movement," Communication, Culture \& Critique, volume 5, number 4, pp. 483-509.

doi: http://doi.org/10.1111/j.1753-9137.2012.01141.x, accessed 31 May 2016.

N. Denzin, 2001. Interpretive interactionism. Second edition. Thousand Oaks, Calif.: Sage.

M. do Val, 2012. "Pacificação no Rio incentiva migração de traficantes para o Espírito Santo," at

http://gazetaonline.globo.com/ conteudo/2012/10/cbn vitoria/comentaristas/marcos do val/1365846-pacificacao-no-rioincentiva-migracao-de-traficantes-para-o-espirito-santo.html, accessed 2 June 2014.

J. Earl and K. Kimport, 2011. Digitally enabled social change: Activism in the Internet age. Cambridge, Mass.: MIT Press.

L. Ems, D. Nemer and E. Medina, 2012. "Twitter as an interactive ephemeral communicative space," AoIR Internet Research 13.0, at http://aoir.org/conference-papers/, accessed 31 May 2016.

C. Ferraz and B. Ottoni, 2014. "State presence and urban violence: Evidence from the pacification of Rio's favelas," paper presented at meeting of the Brazilian Econometric Society; version at https://editorialexpress.com/cgi-

bin/conference/download.cgi?db name=SBE36\&paper id=120, accessed 31 May 2016.

D. Freelon, C. McIlwain and M. Clark, 2016. "Beyond the hashtags: \#Ferguson,\#Blacklivesmatter, and the online struggle for offline justice" Center for Media \& Social Impact, School of Communication, American University (29 February), at http://cmsimpact.org/resource/beyond-hashtags-ferguson-blacklivesmatter-online-struggle-offline-justice/, accessed 31 May 2016.

C. Fuchs, 2012. "Social media, riots, and revolutions," Capital \& Class, volume 36, number 3, pp. 383-391. doi: http://doi.org/10.1177/0309816812453613, accessed 31 May 2016.

T. Gordon, J. Holland and E. Lahelma, 2001. "Critical ethnography in educational settings,” In: P. Atkinson, A. Coffey, S. Delamont, J. Lofland and L. Lofland (editors). Handbook of ethnography. London: Sage, pp. 188-203.

E. Hargittai, 2002. "Second-level digital divide: Differences in people's online skills," First Monday, volume 7, number 4, at http://firstmonday.org/article/view/942/864, accessed 31 May 2016.

S. Harrison and P. Dourish, 1996. "Re-place-ing space: The roles of place and space in collaborative systems," CSCW '96: Proceedings of the 1996 ACM Conference on Computer Supported Cooperative Work, pp. 67-76. doi: http://doi.org/10.1145/240080.240193, accessed 31 May 2016.

P. Howard and M. Hussain, 2011. "The role of digital media," Journal of Democracy, volume 22, number 3, pp. 35-48. doi: http://doi.org/10.1353/jod.2011.0041, accessed 31 May 2016.

M. Ito, S. Baumer, M. Bittanti, d. boyd, R. Cody, B. Stephenson, H.. Horst, P. Lange, D. Mahendran, K.. Martínez, C. Pascoe, D. Perkel, L. Robinson, C. Sims and L. Tripp, 2010. Hanging out, messing around, and geeking out: Kids living and learning with new media. Cambridge, Mass.: MIT Press. 
S. Kamel, 2014. "Egypt's ongoing uprising and the role of social media: Is there development?" Information Technology for Development, volume 20, number 1, pp. 78-91.

doi: http://doi.org/10.1016/j.bushor.2009.09.003, accessed 31 May 2016.

A. Kaplan and M. Haenlein, 2010. "Users of the world, unite! The challenges and opportunities of social media," Business Horizons, volume 53, number 1, pp. 59-68.

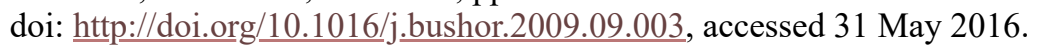

D. Madison, 2012. Critical ethnography: Method, ethics, and performance. Second edition. Thousand Oaks, Calif.: Sage.

E. Mansour, 2012. "The role of social networking sites (SNSs) in the January 25th Revolution in Egypt," Library Review, volume 61, number 2, pp. 128-159.

doi: http://dx.doi.org/10.1108/00242531211220753, accessed 31 May 2016.

S. McLennan, 2015. "Techno-optimism or information imperialism: Paradoxes in online networking, social media and development," Information Technology for Development.

doi: http://doi.org/10.1080/02681102.2015.1044490, accessed 31 May 2016.

J. Miranda, 2013. "Confusão no Shopping Vitória deixa clientes em pânico,” A Gazeta, Vitória (30 November), at http://gazetaonline.globo.com/_conteudo/2013/11/noticias/cidades/1470338-confusao-no-shopping-vitoria-deixa-clientesem-panico.html, accessed 31 May 2016.

L. Morgan, 2011. "Understanding the digital divide: A closer examination of the application of Web 2.0 technologies by undergraduate students," International Journal of Learning, volume 17, number 10, pp. 343-350, and at http://ijl.cgpublisher.com/product/pub.30/prod.2996, accessed 31 May 2016.

D. Nemer, 2015a. "Online favela: The use of social media by the marginalized in Brazil," Information Technology for Development.

doi: http://doi.org/10.1080/02681102.2015.1011598, accessed 31 May 2016.

D. Nemer, 2015b. "Rethinking digital inequalities: The experience of the marginalized in community technology centers," Ph.D. dissertation, School of Informatics and Computing, Indiana University, at

https://scholarworks.iu.edu/dspace/bitstream/handle/2022/20349/Nemer\%202015.pdf, accessed 31 May 2016.

D. Nemer, 2013. "Beyond Internet access: A study of social and cultural practices in LAN houses," Selected Papers of Internet Research, at http://aoir.org/conference-papers/, accessed 31 May 2016.

D. Nemer and G. Freeman, 2015. "Cross platform impression management: A cultural study of Brazilians and indians on Facebook and Orkut," Journal of Technologies and Human Usability, volume 10, number 2, pp. 1-15, at http://jthu.cgpublisher.com/product/pub.296/prod.18, accessed 31 May 2016.

D. Nemer and P. Reed, 2013. "Can a community technology center be for-profit? A case study of LAN houses in Brazil," CIRN Prato Community Informatics Conference 2013, at

http://ccnr.infotech.monash.edu/assets/docs/prato2013_papers/nemerreedprato2013.pdf, accessed 31 May 2016.

L. Nossa and J. Borges, 2013. "Manifestação leva 100 mil as ruas de Vitória e minoria destrói cidade," Gl Globo Rio de Janeiro (20 June), at http://g1.globo.com/espirito-santo/noticia/2013/06/manifestacao-leva-100-mil-ruas-de-vitoria-eminoria-destroi-cidade.html, accessed 31 May 2016.

L. Nossa, L. Tedesco and J. Borges, 2013. "Polícia dispersa protesto em frente à casa do governador do ES," G1 Globo Rio de Janeiro (17 June), at http://g1.globo.com/espirito-santo/noticia/2013/06/policia-dispersa-protesto-em-frente-casado-governador-do-es.html, accessed 31 May 2016.

T. O'Reilly, 2007. "What is Web 2.0: Design patterns and business models for the next generation of software," Communications \& Strategies, number 65, pp. 17-37, at https://mpra.ub.unimuenchen.de/4578/1/MPRA_paper_4578.pdf, accessed 31 May 2016.

J. Perlman, 2010. Favela: Four decades of living on the edge in Rio de Janeiro. New York: Oxford University Press.

M. Pochmann, 2013. "Mobilidade Social No Capitalismo E Redivisão Internacional Da Classe Média," In: D. Bartelt (editor). A "Nova classe média" no Brasil como conceito e projeto político. Rio de Janeiro: Fundação Heinrich Böll, p. 156.

N. Rangaswamy and S. Nair, 2012. "The PC in an Indian urban slum: Enterprise and entrepreneurship in ICT4D 2.0," Information Technology for Development, volume 18, number 2, pp. 163-180.

doi: http://doi.org/10.1080/02681102.2011.643211, accessed 31 May 2016. 
R. Recuero, 2014. “O rolezinho na mídia social: Discurso e violência simbólica,” In: L. Oliveira and V. Baldi (editors). Insustentável leveza da Web - Retóricas, dissonâncias e práticas na Sociedade em Rede. Salvador: Editora da UFBA, pp. $1-25$.

M. Reis, 2014. “Análise e adequação do conceito de 'nova classe média' à realidade brasileira," Universidade Federal do Rio Grande do Sul, at http://hdl.handle.net/10183/109403, accessed 31 May 2016.

H. Rubin and I. Rubin, 2012. Qualitative interviewing: The art of hearing data. Third edition. Thousand Oaks, Calif.: Sage.

A. Saad-Filho, 2013. "Mass protests under 'left neoliberalism': Brazil, June-July 2013,” Critical Sociology, volume 39, number 5, pp. 657-669.

doi: http://doi.org/10.1177/0896920513501906, accessed 31 May 2016.

J. Schradie, 2011. "The digital production gap: The digital divide and Web 2.0 collide," Poetics, volume 39, number 2, pp. $145-168$.

doi: http://doi.org/10.1016/j.poetic.2011.02.003, accessed 31 May 2016.

Y. Takhteyev, 2012. Coding places: Software practice in a South American city. Cambridge, Mass.: MIT Press.

K. Toyama, 2015. Geek heresy: Rescuing social change from the cult of technology. New York: PublicAffairs.

L. Trigo, 2013. "Alguém ainda acha que eram apenas 20 centavos?” G1 - Máquina de Escrever (21 June), at http://g1.globo.com/platb/maquinadeescrever/2013/06/21/alguem-ainda-acha-que-eram-apenas-20-centavos/, accessed 31 May 2016.

Z. Tufekci and C. Wilson, 2012. "Social media and the decision to participate in political protest: Observations from Tahrir Square," Journal of Communication, volume 62, number 2, 363-379.

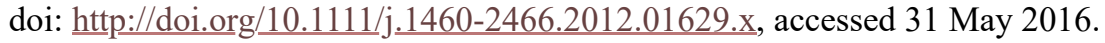

J. van Dijck and D. Nieborg, 2009. "Wikinomics and its discontents: A critical analysis of Web 2.0 business manifestos," New Media \& Society, volume 11, number 5, pp. 855-874.

doi: http://dx.doi.org/10.1177/1461444809105356, accessed 31 May 2016.

M. Warner, 2005. Publics and counterpublics. New York: Zone Books.

S. Wyche, A. Forte and S. Yardi Schoenebeck, 2013. "Hustling online: Understanding consolidated Facebook use in an informal settlement in Nairobi," CHI '13: Proceedings of the SIGCHI Conference on Human Factors in Computing Systems, pp. 2,823-2,832.

doi: http://dx.doi.org/10.1145/2470654.2481391, accessed 31 May 2016.

\section{Editorial history}

Received 27 May 2016; accepted 28 May 2016.

\section{(c) (1)}

"Rethinking social change: The promises of Web 2.0 for the marginalized" by David Nemer is licensed under a Creative Commons Attribution 4.0 International License.

Rethinking social change: The promises of Web 2.0 for the marginalized by David Nemer.

First Monday, Volume 21, Number 6 - 6 June 2016

https://journals.uic.edu/ojs/index.php/fm/article/download/6786/5516

doi: http://dx.doi.org/10.5210/fm.v21i6.6786 